\title{
Иван Грозный: интермедиальность и трансформация образа.
}

А.А.Пауткин

\section{Abstract:}

This article analyzes at some issues related to the history and cinema in Russia.

Keywords: Russian cinema; Russian history; Ivan Groznyi.

Фигура первого русского царя противоречива. Н.И.Либан в своих лекциях, говоря о публицистике XVI века, отмечал: «К «Истории» Андрея Курбского до сих пор обращаются исследователи - и те, кто считает Ивана IV злодеем, и те, кто считает его героем. (Все зависит от исторической ситуации: в сталинское время он был «грозен только с врагами», а в либеральные - представлялся ужасным преступником. Мы не будем пытаться разрешить этот спор.)» ${ }^{1}$ Действительно, оценки деятельности Ивана Грозного не только в новое время отличались друг от друга весьма существенно. Уже в начале XVII в. можно заметить их неоднозначность. В «Летописной книге», приписывавшейся то М.И.Катыреву-Ростовскому, то С.И.Шаховскому, читаем: «...На рабы своя, от Бога данныя ему, жестокосердъ велми, на пролития крови и на убиение дерзостенъ и неумолимъ. Множество народу от мала и даже и до велика при царстве погуби, многая грады своя поплени, и многия святительския чины заточи и смертию немилостивою погуби, и иная многия содеяхъ на рабы своя, и много жен и дщерей блудом оскверниста. Той же царь Иван многия и благая сотвори...» ${ }^{2}$. В IX томе своей «Истории Государства Российского» Н.М.Карамзин писал об этом правителе: «Характер Иоанна, героя добродетели в юности, неистового кровопийцы в летах мужества и старости, есть для ума загадка» .

Уже в XIX в. многие писатели давали свой ответ на эту загадку. Вообще в нашей культуре заметны периоды повышенного интереса к эпохе Ивана Грозного. Они в значительной мере обусловлены внешними причинами идеологического, политического свойства. Подобные «приливно-отливные» процессы за последние полтораста лет представляются своеобразными циклами художественной активности литераторов и подключившихся к ним позднее деятелей кино. Обращения кинематографистов к образу Ивана IV, как правило, связаны с использованием литературных источников, а нередко это экранизации классических произведений. Поэтому правомерно рассматривать кино и литературные интерпретации образа грозного царя параллельно.

В новой литературе и культуре со всей очевидностью выделяются 60-е гг. XIX в. и 3040 гг. века XX. Оценки деятельности Ивана тут диаметрально противоположны. После 
цензурных послаблений времени Александра II появились роман, баллады, драма А.К.Толстого. Особенно в этот период многочисленны исторические драмы (И.И.Лажечников - «Опричник» ${ }^{4}$, Л.А.Мей - «Царская невеста», Д.В. Аверкиев «Слобода Неволя», А.Н.Островский - «Василиса Мелентьева»). У всех авторов пореформенной поры царь Иван изображается жестоким деспотом. Создавая свой образ правителя-тирана, они во многом опирались на материалы «Истории Государства Российского» Карамзина.

Может быть, только А.Н.Майков, знаток старины и переводчик «Слова о полку Игореве», предложил в своем известном стихотворении «У гроба Грозного» (1887) более сложную трактовку образа царя Ивана. Так и кажется, что написано стихотворение не в XIX в., в эпоху Александра III, а пятьюдесятью годами позже. Эти строки, бесспорно, напоминают историко-тематические пристрастия А.Н.Толстого. Майков утверждал: народный плач о грозном царе будет громче, «чем этот шип подземный боярской клеветы и злобы иноземной...». Тут же прямо связывались дела Ивана и Петра I: «И труд был завершен уж подвигом Петра» ${ }^{5}$. Напомним, что сближения Ивана и Петра I появились уже в начале XVIII в. Г.Н.Моисеева приводила в качестве примеров надписи на Триумфальных воротах, где под изображением Ивана помещалось слово «начал», а Петра - «закончил», а также справедливо указывала на воображаемый разговор Ивана и Петра в ломоносовской «Оде на взятие Хотина» ${ }^{6}$.

Если присмотреться к библиографии исследований о времени Ивана Грозного, публикациям текстов, с ним связанных, можно заметить некую лакуну между началом 20 х и рубежом 40-50-х гг. ХХ в. Компенсируется это научное молчание средствами литературы и кино. То есть популяризации эпохи служит именно художественный язык. Роман, пьеса, кинофильм в эту пору создают совершенно иной образ. Во всю мощь нашим соотечественникам будет явлен не царь-деспот, а царь-реформатор, положительный, хотя и не лишенный противоречий, пример прогрессивного правителя, преодолевшего многочисленные трудности на пути укрепления российской государственности.

Конечно, художественная ценность этих произведений советского искусства различна. Это почти забытые сегодня повести К.Шильдкрета и Г.Шторма, и роман-трилогия В.И.Костылева, удостоенный Сталинской премии в 1948 г., и драматическая повесть А.Н.Толстого «Иван Грозный», и гениальный фильм С.Эйзенштейна, появившиеся почти одновременно.

А.Н.Толстой в сталинское время дал свой ответ на мучительные вопросы, касающиеся оценки правления Ивана IV, достижений его тревожного царствования. Является ли такая литературная трактовка историей, не подтверждаемой самой историей? В какой мере 
талантливый литератор был независим в своих прочтениях документов XVI в.? Действительно, советский писатель обладал гораздо более широкими по сравнению с авторами XIX в. возможностями в области привлечения опубликованных материалов эпохи Грозного. Как бы там ни было, даже в период идеализации царя - реформатора именно знакомство с источниками отвратило Толстого от мысли о драматической трилогии (изложение событий доведено до 1571 г.). Увлеченность временем, человеком «бешеного темперамента» вступали в противоречие с документальными свидетельствами, ведь писателю была доступна не только переписка Ивана с Андреем Курбским, сочинения Ивана Пересветова и послания царя Василию Грязному. Всё это реминисценциями и цитатами присутствует в «Орле и орлице» и пьесе «Трудные годы». Писателю уже хорошо известна опубликованная в «Русской исторической библиотеке» (Т.XXXI, 1914) «История о великом государе Московском» Андрея Курбского. Это сочинение опального боярина, созданное для европейского читателя, постепенно из рассказа о правителе превращалось в удручающий мартиролог его жертв.

Конечно, в XX в. средневековая традиция явлена в различных формах. Это могут быть попытки художественной реставрации Древней Руси, а может быть и ее своеобразная реконструкция, учитывающая запросы власти, социально-политическую потребность, массовый вкус, сформированный той же властью. В случае с образом Ивана IV это именно так. И, видимо, иначе быть не может, уж слишком это знаковая, затрагивающая глубины национального менталитета фигура. Работа драматурга тут в чем-то сродни труду древних писцов, компилировавших различные виды текстов, помещавших рядом документ и легенду, факт и вымысел. Так создавался идеальный образ правителя. И на возникающий вопрос: возможна ли вторая «волна» уже не средневековой литературной идеализации - приходится ответить утвердительно.

Массовое искусство кино, появившееся в начале XX в., демонстрирует те же процессы и циклы, только на более коротком столетнем отрезке. Короткометражный фильм «Смерть Иоанна Грозного»(1909) режиссеров В.Гончарова и Я.Протазанова был снят по мотивам пьесы А.К.Толстого (роль Ивана Грозного сыграл А.Славин). А в 1915 г. А.Иванов-Гай снял фильм «Царь Иван Васильевич Грозный». В основе его сценария пьеса Л.Мея «Псковитянка» (главную роль исполнил Ф.И.Шаляпин). Как видим, еще немые и достаточно короткие фильмы дореволюционной поры опираются на тексты, хотя и сильно адаптированные, литературных произведений 60-х гг. ХІХ в. Подозрительный и жестокий царь - виновник расправы над Новгородом и Псковом. Кстати, заметим, что на знаменитом памятнике М.О.Микешина «Тысячелетие России», установленном в Великом 
Новгороде в 1862 г., среди десятков фигур исторических деятелей нет и намека на Ивана IV.

В 40-е гг. XX в. все меняется. С.Эйзенштейн в самом известном фильме на эту тему показывает сложный образ царя, укрепляющего единовластие. Его Грозный в исполнении Н.Черкасова незабываем. Он борется с боярским заговором, покоряет Казань и т.д. Но это вместе с тем фигура трагическая, полная противоречий. Вторая, уже цветная, серия «Ивана Грозного» оказалась, как известно, неугодной власти. Слишком мрачной вырисовывалась опричнина, в которой тогдашние идеологи стремились видеть лишь «прогрессивное опричное войско». Подняться выше творения Эйзенштейна при раскрытии этой темы кинематограф не смог. Но подтвердилась все та же цикличность. С завершением советской эпохи, на фоне цензурных послаблений усилились извечные российские размышления о власти, деспотии и демократических формах правления. Как и в начале века, кинематографисты обратились к литературной первооснове, и вновь это было произведение 1861 г. - роман А.К.Толстого «Князь Серебряный». По его мотивам Г.Васильев снял фильм «Царь Иван Грозный» (1991, актеры: К.Кавсадзе - Иван, И.Тальков - князь Серебряный). Эта лента не вызвала заметного резонанса, да и время, когда ее смог увидеть зритель, не способствовало развитию искусства кино. Вероятно, и зрительские ожидания претерпели изменения. Но процесс разоблачительного воплощения на экране одной из самых мрачных эпох в истории России вновь обозначился.

Апофеозом его стал фильм П.Лунгина «Царь» (2009), в котором трудно обнаружить какие-либо отсылки к текстам XVI в. В центре внимания авторов нравственное противостояние Ивана и митрополита Филиппа. Прекрасные актерские работы П.Мамонова и О.Янковского, мистическая символика не придали картине ожидаемой глубины. Ужас и мрак, паранойя власти, садизм и бессмыслица жестокости - вот что увидел зритель, который и так все это знает о царствовании Ивана $\mathrm{IV}^{7}$. Не говоря о слабости драматургии, заметим: нужна значительная, новая мысль, художественно воплощенная идея для того, чтобы повторить хотя бы успех картины С.Эйзенштейна. Фильм П.Лунгина не столько о XVI в., сколько об эпохе, когда снимал свой шедевр Эйзенштейн. Получился своеобразный триллер об ужасах тоталитаризма. Эйзенштейн же, напротив, в условиях сталинской диктатуры сумел избежать прямолинейной апологетики.

Сегодня уже невозможно изображение правления Ивана IV со знаком плюс. И, тем не менее, убедительно показать трагедию деспотической власти в ее абсолютных формах сложнейшая художественная задача, далекая от натуралистических запросов современного массового зрителя. Фильм «Царь» вызвал комичные по своей сути, но весьма показательные отклики в печати. Прозвучали обвинения режиссера в 
очернительстве истории, неверном показе роли церкви и, конечно, в извращенной трактовке образа великого правителя России, достойного почитания как святого. Подобные свидетельства могут лишь подтверждать тезис о том, что отмеченная цикличность в отражении литераторами и кинематографистами фигуры Ивана Грозного есть проявление разнонаправленной «потенциальной энергии», сокрытой до поры в национальном сознании ${ }^{8}$.

Впрочем, в подобных реакциях нет ничего удивительного. Еще историк Н.И.Костомаров, не чуждый, как известно, литературного творчества, открывал свою работу «Личность царя Ивана Васильевича Грозного» рассуждением о том, как историки пересматривают оценки Карамзина. При этом он приводил высказывание по поводу поэтических воспроизведений характера Ивана Грозного, принадлежащее К.Н.БестужевуРюмину, который одобрял А.Н.Майкова и видел вред от произведения А.К.Толстого (трагедия «Смерть Иоанна Грозного»).

В 2009 г. впервые был показан 16-ти серийный телевизионный фильм «Иван Грозный» (реж. А.Эшпай). Картина отразила стремление кинематографистов разобраться в предыстории правления Ивана Грозного, неторопливо показать судьбы людей этой тревожной эпохи. К сожалению, и эта большая работа прошла без особого резонанса и не вызвала зрительских симпатий. Появятся ли в ближайшее время новые грандиозные кинопроизведения на эту тему, сказать трудно. Возможно, очередной цикл, но уже не в литературоцентричную эпоху нашей культуры завершен.

Республиканец и борец с деспотией А.Н.Радищев в «Путешествии из Петербурга в Москву» (глава «Новгород») писал об Иване Грозном: «Сей гордый, зверский, но умный властитель» ${ }^{9}$. Какая из сторон этой загадочной личности способна еще заинтересовать художника, покажет будущее.

Существуют и иные кинематографические обращения к событиям XVI в., где образ царя Ивана не является центральным. Таков, например, фильм «Ермак» (1996, реж. В.Краснопольский и В.Усков). Роль Ивана Грозного здесь сыграл Е.Евстигнеев. Зритель вновь встречается с жестоким, непредсказуемым в своих проявлениях самодержцем, подвергающим изощренным пыткам и правого, и виноватого. Подобные обращения к образу царя Ивана не представляют собой каких-либо новых художественных тенденций, a являются скорее добротной иллюстрацией широко известных черт деспотичной личности.

Пьеса М.А.Булгакова «Иван Васильевич» (1936), по мотивам которой был поставлен фильм Л.Гайдая «Иван Васильевич меняет профессию» (1973), при жизни автора не публиковалась и не ставилась на сцене театра (запрещена после первой репетиции). 
Травестированное, комедийное прочтение образа Ивана Грозного, нарочито снимающее весь ужас знаковой исторической личности, прозвучало диссонансом в эпоху идеализации. Но пьеса смогла возродиться в фильме, время выхода которого на экран находится как бы на равном удалении от периода нарочитой апологетики и сегодняшней эпохи обличения ${ }^{10}$. Любопытно, что в комедии Гайдай использовал костюмы, сохранившиеся еще от постановки С.Эйзенштейна. К этому же времени (1975) относится премьера балета «Иван Грозный» на музыку С.Прокофьева к фильму Эйзенштейна (либретто Ю.Григоровича).

Подведем итоги. Ни один другой правитель русского средневековья не вызывает подобных колебаний в национальном культурно-историческом сознании. В среднем через два поколения заметно усиление общественного и как следствие творческого интереса к фигуре Ивана Грозного. В искусстве советского периода был установлен интермедиальный паритет в запечатлении образа царя Ивана. Третий цикл рубежа веков, начавшийся с очередного обращения к текстам XIX века, которые оказались весьма востребованными кинематографистами, демонстрируют уже торжество визуальных версий и слабость собственно литературной составляющей. Видеоряд становится первичным. В массовой литературе возникло такое явление, как новеллизация. В данном случае это, например, превращение сценария фильма «Царь» в роман А.Иванова «Летосчисление от Иоанна».

Статистически среди текстов, посвященных правлению Ивана IV, преобладают драматические произведения, что дает театру и кино особые преимущества в реализации этой темы. Утрата историческим романом своих прежних позиций, ослабление интереса к документу, литературному источнику ведут к торжеству иллюстративности. Тем не менее, фигура царя Ивана слишком грандиозна для жанра, например, так называемого славянского фэнтэзи. Поэтому представляется вполне возможным появление значительного романного повествования, обобщающего достижения современного гуманитарного знания.

Следует отметить, что в сфере изобразительного искусства не наблюдается отмеченная цикличность. Знаковые образы Ивана IV, созданные в 70-90-е гг. XIX в. М.М.Антокольским (1871), И.Е.Репиным (1885) и В.М.Васнецовым (1897), так и остаются доныне своеобразным художественным эталоном. Несколько полотен конца XIX в., появившихся, скорее, под впечатлением «Василисы Мелентьевой» А.Н.Островского или произведений оперного искусства, малоизвестны ныне. Они стали лишь эпизодом в развитии русской исторической живописи. ХХ в., включая художников-неоклассиков, ничего не добавил к воплощению этой темы. Назовем лишь работы И.Глазунова, 
вернувшегося к истокам и проиллюстрировавшего роман А.К.Толстого «Князь

\section{Серебряный».}

1 Либан Н.И. Литература Древней Руси: Лекции - очерки. М., 2000, С.95.

${ }^{2}$ Памятники литературы Древней Руси. Конец XVI - начало XVII веков. М., 1987. С.422.

${ }^{3}$ Карамзин Н.М. История Государства Российского. Книга третья. Тома IX,X,XI,XII. M., 1998. T.IX. С.259.

${ }_{5}^{4}$ Пьеса Н.И.Лажечникова была написана еще в 1843 г., но долго запрещалась цензурой.

${ }^{5}$ Майков А.Н. Соч. в двух томах. Т.І. М., 1984. С.452.

${ }^{6}$ Моисеева Г.Н. Древнерусская литература в художественном сознании и исторической мысли России XVIII века. Л., 1980. С.216.

${ }^{7}$ На это же общепринятое восприятие эпохи опирается В.Сорокин в своей гротескно-порнографической антиутопии «День опричника».

${ }^{8}$ Телевизионное шоу «Суд истории», построенное на столкновении полярных оценок исторических событий и личностей, в свою очередь наглядно продемонстрировало существующий в обществе диапазон мнений и устойчивых пристрастий.

${ }_{9}^{9}$ Радищев А.Н. Избранные философские сочинения. Л.,1949. С.74.

10 Современное использование образа Ивана Грозного в телевизионной рекламе восходит именно к булгаковской трактовке, приобретшей широкую популярность благодаря фильму Гайдая. 